\title{
SCJ トヒッ⿻
}

\section{我が国の学術研究推進の重要性についての会長談話}

国費の無駄な投資を減らし、より適切な国家予算を作るための一つの方策として、現在、行政刷新会 議における事業仕分けが進んでいます。この事業仕分けは国民に対してオープンな状態で行われていて 革新的であり、国民から広く受け入れられているものと理解します。一方で、特に基礎科学や科学技術 関連の項目についての厳しい判定を懸念する声も聞こえてきておりますので、この機会に中・長期的視 野に立った学術研究推進の重要性について改めて述べたいと思います。

日本学術会議はすでに、「我が国の未来を創る基礎研究の支援充実を目指して」(平成20年 8 月）と題 する提言を発出しておりますが、その中で、将来を見据えた基礎研究への投資こそが我が国が真の文化 国家として世界的な学術の発展及び人類の福祉の向上に貢献するものであることを述べました。基礎研 究を含む学術研究を大切にする心に支えられて、科学・技術を推進し、その成果を基に社会制度や意識 改革を含むイノベーションを創出し、同時に次代を担う人達を育成することこそが、資源・エネルギー に乏しい我が国が先進国の中でプレゼンスを高め国際貢献を果たすことができるための唯一の道である と考えます。

科学・技術の成果は一朝一夕に成るものでなく、多くの研究者による実験、データ収集、解析・評価、 証明など長期にわたる継続的努力の積み重㱛によっています。また、多くの研究計画は多数の研究者の 議論の積み重ねによって作られています。したがって、基礎研究への投資がたとえ短期間であっても大 きく減少することは、研究を実際に担う人材の離散を生じるだけでなく、国際競争力の低下をも招きます。 この状態からの回復は困難であり、仮に回復できるとしても、それまでに膨大な時間と資金が必要となり、 国際間の大競争時代にあって国家的損失を招くことは明らかです。

新政権が社会に吹き込む新風に対して、国民は大きな期待を寄せています。鳩山内閣は、総理を筆頭 に理系出身の多くの閣僚を含み、科学・技術に深い造詣と理解を有するものと信じております。また、 菅国家戦略担当・科学技術政策担当大臣は、来年度予算の柱として、雇用、環境、景気、子どもに科学・ 技術を加えた5つのKによって、景気回復からできれば成長の方向へつなげていきたいとの方向を打ち出 しており、私達科学者も大いに期待しています。我が国として、是非人文・社会科学を含む基礎研究か ら開発研究に至るまでの広い意味での学術研究を重視し、国家百年の計を過つことの無いように心から 願っています。

平成 21 年 11 月 20 日

日本学術会議会長 金澤一郎 